\title{
User Perception on Urban Light Rail Transit
}

\author{
Seuk Yen Phoong ${ }^{1, *}$, Seuk Wai Phoong ${ }^{2}$, Sedigheh Moghavvemi ${ }^{2}$, Kok Hau Phoong ${ }^{3}$ \\ ${ }^{1}$ Department of Mathematics, Universiti Pendidikan Sultan Idirs, Malaysia \\ ${ }^{2}$ Department of Operations and Management Information Systems, University of Malaya, Malaysia \\ ${ }^{3}$ Faculty of Management and Information Technology, Sultan Azlan Shah University, Malaysia
}

Received July 28, 2019; Revised October 8, 2019; Accepted December 15, 2019

Copyright $\odot 2019$ by authors, all rights reserved. Authors agree that this article remains permanently open access under the terms of the Creative Commons Attribution License 4.0 International License

\begin{abstract}
Public transport is a shared passenger transport service available for public use. Increased population is accompanied by the increased demand for private vehicles. The exponential growth in the number of private vehicles will result in negative impacts such as air pollution, excessive noise, and traffic congestion. Additionally, customers' perceptions on different aspects include safety, operation or time, comfortableness and cleanness of public transportation that are also essential in affecting their mode of choice when travelling. The public transport that is discussed in this paper is light rail transit. This paper intends to investigate the main purpose of using light rail transit and elucidate the public perspective of the light rail transit via factor analysis and correlation analysis. A questionnaire with five-point Likert scale was designed, and data were randomly selected from 200 light rail transit users in Kuala Lumpur, Malaysia. The results revealed that the majority of the customers use light rail transit to school or university. Moreover, most of the users satisfy with the safety, operation, cost, comfortableness and cleanness of the light rail transit. This can be concluded that light rail transit provides mobility and choice for everyone in the context of efficiency, health and safety, affordability, accessibility, and environmental friendliness.
\end{abstract}

Keywords Light Rail Transit, Public Transport, Safety, Comfortable, Affordability

\section{Introduction}

Kuala Lumpur is the economic capital, as well as the cultural and financial centre of Malaysia. Due to its multirole nature, its municipality experiences many problems, such as traffic congestion, emission of carbon dioxide, and excessive noise pollution. The ever increasing amount of vehicles annually can be problematic in the future in the context of transportation governance, and the introduction of public transport is expected to alleviate traffic congestion in the city.

The problems pertaining to the public transportation system in Kuala Lumpur are the lack of integration and focus. The government does not actively promote the use of public transportation, which indirectly influences daily life. According to the statistics in 2017 , the average daily ridership of the public transport in 2017 was 638,608 in Kuala Lumpur. The average time a person spent every day in traffic congestion is $\sim 53$ minutes in Kuala Lumpur. $\sim 83 \%$ of the respondents in Kuala Lumpur wish to own a car in the next half decade, which will serve to only exacerbate the current congestion problem.

To pursue green growth in Malaysia, the government invested public transport in its effort to lower carbon mobility. As per the Eleventh Malaysia Plan [1], a single occupant car ranks first of the ground public transport which emits carbon dioxide, followed by buses and trains. The use of public transport is expected to reduce congestion and minimize environmental pollution. Also, clean and comfortable facilities, increased train frequencies and punctuality would also play a role in encouraging the public to use public transportation in their daily lives. The public transport system is required to be more market-oriented and competitive, which can only be realized when the public's needs, expectations, and behavior are identified and addressed appropriately.

Public transportation can be defined as a shared passenger transport service which is available for use by the general public, as distinct from modes including buses, taxi, Monorail and transit trains. In Malaysia, the modes of public transportation are buses, taxis, KL Monorail, commuter, Rapid KL, light rail transit (LRT) and mass rapid transit (MRT). The LRT and MRT are known as metro rail transit which is an emerging transit system introduced by Malaysian government. These system are available to the public which may require fares, and run at scheduled times. The purpose of introducing or expanding public transport is to address traffic jam problem in a densely populated area like Kuala Lumpur. The benefit of this emerging transit system is to minimize the waiting 
time, to envisage improving the poor and inadequate public transportation coverage at Kuala Lumpur.

This study focuses on one of the most frequently used public transportation in Kuala Lumpur, which is light rail transit (LRT). This is because LRT is the most frequently used transportation as compared to others. It can easily convey users from suburbs far off cities to the heart of Kuala Lumpur. For instance, the Kelana Jaya LRT station is one of the most frequently used stops for residents who work in the centre of Kuala Lumpur. While for the Ampang LRT line, it's also frequently used by the office workers who need to convey from other suburban areas to the heart of Kuala Lumpur.

Light rail transit, also known as LRT, is an urban rail transport service that has two major routes, including Kelana Jaya and Ampang LRT line in Malaysia. This rail transit services serve as a large part of the national capital and largest city, Kuala Lumpur in Malaysia. The current daily ridership of LRT is over 464,000 users per day which has the highest passenger loads as compared to other public transports.

However, there are a few cases about the delay of LRT. In 2018, the signaling problem caused over two hours of delay at peak hour which resulted in many passengers being stranded at several stations. The incident led some of the passengers to vent out their disappointment over the rail transit service through social media [2]. Other issues about the weaknesses of LRT were poor customer service quality, overcharging, cleanness and etc. Thus, this study intends to elucidate public perspective on the environment, service, and system adopted by the urban LRT. It is expected that Rapid Rail Sdn. Bhd. and Prasarana Malaysia Berhad take into account these factors when evaluating residents' usage of LRT. The objectives of this study include:

i. Determining the main usage of LRT users in Kuala Lumpur.

ii. Elucidating public perception on the urban LRT.

iii. Determining the highest correlation between the items on the usage of LRT using factor analysis.

\section{Literature Review}

Public transport is known to be environmentally friendly when relative to private modes of transportation. Public transportation includes buses, coaches, rapid transit, trains, ferries, and airlines, most of which are outright owned or financed by the state or private individuals. According to Bachok et al. [3], public transportation helps maintain accessibility while also expanding economic opportunities, reduce fuel consumption, and mitigate environmental concerns. He also pointed out that the public transportation system consists of all multiple occupancy vehicle services which were designed to transport passengers, such as vans, buses, taxis, or rails or other transportation, which are publicly or privately owned and make available the services to the general public.

Public transport is regarded as a need in many parts of the world. A transportation system is regarded to be dismal if its service is poor [4]. Public transportation plays a substantial role in our lives due to the fact that it improves our quality of life by expediting traffic, which reduces costs while also creating jobs. It provides accessibility to those who cannot drive, or those who cannot afford to do so. Public transport service includes multiple tenancy vehicles services designed to transport passengers on local and regional routes and their corresponding sub-systems. Malaysia has many public transportation systems that are in operation, such as buses, taxis, trishaws, and trains.

However, most people are now highly dependent on car travel [5]. Metropolitan centers are overwhelmed with unmanageable trends in the transportation sector due to escalation in energy use, pollution, and traffic congestion. These problems are even more prominent in the case of developing cities because the vehicle growth rate is far superior to the growth rate of transport infrastructure. The progressively active car use in the cities contributed to increased accessibility problems, due to traffic congestion and parking problems. Traffic congestion is a significant problem faced by many urban areas in Malaysia, which can be mitigated by the usage of public transport. The use of public transport can reduce traffic accidents, congestion and parking problems. Although car use is the most popular visitor transport mode, congestion, pollution, traffic problems, and demands for maintainable transport practices led to efforts expanded towards improving public transportation. Public transportation has played an important role in transporting passengers to work and elsewhere, which has the positive effect of reducing traffic congestion [6].

Besides road congestions, private cars also cause serious problems such as $\mathrm{CO}_{2}$ pollution, global warming, and noise. Jain and Khare [7] said that the increasing alteration in motorized mode of transport in urban cities of the developing countries increased the amount of air pollutants. The transport sector is responsible for the emission of more than a quarter of carbon dioxide $\left(\mathrm{CO}_{2}\right)$ globally, as well as sizeable shares of methane $\left(\mathrm{CH}_{4}\right)$ and nitrous oxide $\left(\mathrm{N}_{2} \mathrm{O}\right)$ emissions, making it one of the largest single contributors to global greenhouse gas (GHG) emissions. According to Parry et al. [8], unrestrained emissions of GHG to the atmosphere have warmed the planet to levels never seen before in history. The production of GHG and the global warming not only affect the environment and economy, they also noticeably affect human health. The climate changes caused by global warming have unpredictable impacts on the environment, society, and economy. According to the IEA [9], the global $\mathrm{CO}_{2}$ emissions reached $32.4 \mathrm{Gt}-\mathrm{CO}_{2}$ in 2014, which is an increase of $0.8 \%$ over that of levels reported in 2013. The transportation sector is one of the major contributors to these numbers, at 
a share of 23\% [9], since most vehicles on the road remain dependent on hydrocarbon fuels. Also, the number of automobiles on the road has been increasing in tandem with the global population. Public transport has been touted as a solution to this problem.

According to Santos et al. [10], the rate of vehicle growth is far greater than the rate of growth of transport infrastructure. This means that traffic congestion will be rife in urban centers. Similarly, Khalid et al. [11] also reported that traffic congestion is one of the significant problems faced by many urban areas in Malaysia. The current growth trends in Malaysia are unsustainable, as they are directed towards increased use of private vehicles. The level of investment in road construction increased significantly over the past few years, but the level of investment in public transport does not comport with that of road construction.

The Malaysian government is eager to improve public transport in urban areas of the country. This is in line with its objective of stimulating economic growth and relieving traffic congestion. There are many forms of public transportation in Malaysia, an example of which being the light rail transit (LRT). The LRT is one of the most frequently used public transport services in Kuala Lumpur, being utilized by those going to work, schools, and going about their daily lives. It is constantly being developed and improved over the years. However, it should be pointed out that increased supply does not mean increased demand or satisfaction in the case of the LRT [12]. In order to ensure that the LRT meets its objectives, factors such as frequency, travel time, comfort and cleanliness that were prioritized. Network coverage and safety issues [13] were also mentioned as crucial factors by customers when evaluating the quality of public transport services.

According to Roberts [14], factors affecting the transportation mode for the people include cost, service, product characteristics, capacity, security, and environment. Taking into account the multiple factors that play into the decision and carefully analyzing them will allow us to improve public transport. Botzoris et al. [15] pointed out that the facilities and equipment of public transports are the main factors influencing passengers' perception of service quality. In addition, Leem and Yoon [16] also highlighted the fact that customer satisfaction is an assessment of the services and products. Meanwhile, Aworemi et al. [17] suggested that socioeconomic factor is also important, while Pucher et al. [18] and Zheng and Wu [19] concluded that improving service quality would ultimately be helpful for reputation and profit margins of public transportation.

Comfort and cleanliness are one of the factors affecting customer satisfaction. This can be supported by referring to Irtema et al. [20] states that the level of comfort before and during the journey will affect an user's travelling mood. In addition, overcrowding can be a major setback for public transport users. Overcrowding itself is uncomfortable, especially travelling with annoying passenger's attitude such as talking loudly over the phone. This situation could get much worst during peak hours with students getting to or from classes. Ismail et al. [21] reported that comfortable travel experience appeared to have a strong relationship with the overall satisfaction. This be can supported by Cantwell et al. [22] states that the personal space invasion and crowding is one of the main reasons for user dissatisfaction.

In addition, satisfaction is the gap between customers' perception and expectations towards products or services and their own personal experience on those products or services [23]. It can bemeasured only when consumers have self-experience with the product. Satisfaction is essential for an organization either in public or private sectors as it has been related with customer loyalty and will affect organizations' sustainability [24]. Without the continuous support from customers, a company could not survive in industry for long term. In public transport industry, it is necessary to evaluate user public transport satisfaction to ensure service provider has a clear picture on customers' travel needs and presumption. Sumaedi et al. [25] mentioned that citizens tend to own a private vehicle when they are dissatisfied with the public transport services and it will cause traffic congestion. If the standard of service provided has met with customer perception, they will be satisfied and indirectly the public transport company will get a good reputation. When customers are satisfied with the services provided, they will have the initiative to use public transport as their first choice of travelling transport.

According to Mouwen [26], public transport users emphasized on the service attributes such as on-time performance, travel speed, and service frequency as the most important aspect, followed by the driver behavior and vehicle tidiness. Then, a generic policy is established by Mouwen [26] to achieve the service attributes such as punctuality, frequency, driver behavior and cleanliness that can increase the level of customers' satisfaction. Clarifying the factors affecting the level of satisfaction is the most important variables to the authorities to design policies for encouraging both the actual and potential public transportation users.

\section{Research Methodology}

This project is going to be carried out using quantitative approach. Reviews of secondary sources materials, including article journal, professional magazines and reports will be done to identify the current situation, issues and challenges of the usage of public transport in Kuala Lumpur. The review of literature will enhance the nature of the study and provide focus of the study.

Next, questionnaire is used in this project to evaluate the main usage of the LRT users in Kuala Lumpur; and the 
service quality and customer satisfaction on the usage of LRT.

This questionnaire is divided into two sections which are demographic profile and constructs items. Section A is asking about respondents' personal details and section B is the item about the satisfaction on safety, operation or time, comfortableness and cleanness of LRT. A five-point Likert scale, ranging from 1 (strongly disagree) to 5 (strongly agree) was used in the questionnaire for rating the items in section B. Based on the data collection, the service quality and customer's satisfaction that emerge from the questionnaire will be identified and codified according to the themes. Thereafter, data analysis using factor analysis is used to measure and analyze the gathering data. Moreover, reliability test is also included in this study to measure the reliability and significance of the study (see Table 1).

Table 1. Reliability Coefficients of Instrument

\begin{tabular}{|c|c|}
\hline Cronbach's Alpha & Value of Reliability \\
\hline$<0.67$ & Poor \\
\hline $0.67-0.80$ & Fair \\
\hline $0.81-0.90$ & Good \\
\hline $0.91-0.94$ & Very Good \\
\hline$>0.94$ & Excellent \\
\hline
\end{tabular}

Next, factor analysis is an exploratory tool that can be used to describe the variability obtained and measured from the independent latent variables. This process reduces the information in a model by reducing the dimensions of the observations. Factor analysis can be used in many areas, and is of particular significance in education, sociology, and psychology. The implementation of factor analysis in such areas is mainly for identifying how manifest behaviour can be interpreted in the context of underlying patterns and structures.

This study used factor analysis to analyze the data obtained from the survey. This method is a useful tool for examining the relationship between complex concepts such as socioeconomic status and psychological scales. This can be supported by referring to Sharfuddin [27] that factor analysis is used to show produced clusters of uncorrelated factors for the public transit ridership.

Supposing we have a set of $\mathrm{n}$ random variables, $x_{1}, x_{2}, \ldots, x_{n}$, with means of $\mu_{1}, \mu_{2}, \ldots, \mu_{n}$. Let vector $X$ denote the vector of traits collecting all random variables, $x_{i}$.

$$
X=\left(\begin{array}{c}
x_{1} \\
x_{2} \\
\vdots \\
x_{n}
\end{array}\right)=\text { vector of traits }
$$

Then, assuming that the vector of traits, $X$, is sampled from a population with a population mean vector of:

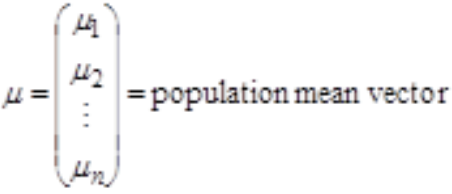

where $\mu_{i}=E\left(X_{i}\right)$ denotes the population with means of variable $i$.

Let $p$ be the unobservable common factors $f_{1}, f_{2}, \ldots, f_{p}$.

Then, the common factors can be collected into a vector, $\mu$.

$$
f=\left(\begin{array}{c}
f_{1} \\
f_{2} \\
\vdots \\
f_{n}
\end{array}\right)=\text { vector of common factors }
$$

The regression coefficients $l_{\mathrm{ij}}$ for multiple regressions are called factor loadings. Factor loadings are coefficients used to explain the correlations between observed variables in a factor pattern matrix. The rule of thumb for factor loading with 0.7 or above represents that the factor extracts sufficient variance from that variable [28]. A factor loading matrix is a matrix of weight or coefficients for the variable. Thus, the factor loading will be collected into a matrix shown below:

$$
L=\left(\begin{array}{cccc}
l_{11} & l_{12} & \cdots & l_{1 p} \\
l_{21} & l_{22} & \cdots & l_{2 p} \\
\vdots & \vdots & & \vdots \\
l_{n 1} & l_{n 2} & \cdots & l_{n p}
\end{array}\right)=\text { matrix of factor loadings }
$$

Thereafter, the errors, $\varepsilon$ are called specific factors with variable $i$. Finally, the matrix notation for factor analysis is:

$$
X=\mu+L f+\varepsilon
$$

From the obtained factor loading, we can determine if there are any correlation(s) between items using correlation analysis. Correlation analysis is used to explain the impact of changes of independent variables on dependent variables [29].

$$
Y_{\mathrm{i}}=\beta_{0}+\beta_{1} x_{1}+\ldots+\beta_{\mathrm{k}} x_{\mathrm{k}}+\varepsilon
$$

where $Y=$ Dependent variable

$\beta=$ Coefficient of Independent Variable

$x=$ Independent Variable

$\varepsilon=$ Random Error

This study attempts to establish a performance evaluation mechanism for consulting residents' perception on the usage of light rail transit in Kuala Lumpur, Malaysia. The sampling technique of the study is random sampling. There are 200 LRT users being selected as respondents and the questionnaire was distributed to LRT users in both Kelana Jaya and Ampang LRT line in Malaysia. The data were analyzed using descriptive statistics, reliability test, validity and factor analysis in SPSS. 


\section{Results and Discussion}

From the result of analysis, the internal consistency of the items in customers' perception on LRT was examined using the reliability test. The Cronbach's Alpha is 0.915, which exceeds the acceptable limit of 0.7 . This can be referred to Tavakol and Dennick [30] that the acceptable range of value for the Cronbach's Alpha is $0.70-0.95$ but a lower alpha could still be reliable if the questionnaire was comprised of lesser questions overall.

Then, a descriptive statistics table is used to describe the information from the respondents. Table 2 shows that there are 90 male and 110 female respondents. In addition, there are 97 respondents of LRT users claiming to own a vehicle, while 103 do not. Also, $31 \%$ of the respondents use LRT for commuting to school/college/university, $18.5 \%$ to work, $26 \%$ shopping, $14 \%$ for recreation, and $10 \%$ for visiting friends/relatives.

Table 2. Demographic Analysis

\begin{tabular}{|c|c|c|}
\hline Variable & $\begin{array}{l}\text { Frequency } \\
(n=200)\end{array}$ & $\begin{array}{l}\text { Percentage } \\
(\%)\end{array}$ \\
\hline \multicolumn{3}{|l|}{ Gender } \\
\hline Male & 90 & 60 \\
\hline Female & 110 & 40 \\
\hline \multicolumn{3}{|l|}{ Have Own Vehicle } \\
\hline Yes & 97 & 48.5 \\
\hline No & 103 & 51.5 \\
\hline \multicolumn{3}{|l|}{ Usage of LRT } \\
\hline $\begin{array}{c}\text { Commuting to } \\
\text { school/college/university }\end{array}$ & 62 & 31 \\
\hline Work & 38 & 18.5 \\
\hline Shopping & 52 & 26 \\
\hline Recreation & 28 & 14 \\
\hline Visiting friends/relatives & 20 & 10 \\
\hline
\end{tabular}

The results of users' perception on LRT based on the comfortableness , cleanness, safety, operation or time and cost are discussed in the Table 3 .

Table 3. Perception on the usage of LRT

\begin{tabular}{|l|c|c|c|c|c|}
\hline \multicolumn{1}{|c|}{ Item } & $\begin{array}{c}\% \\
\text { SD }\end{array}$ & $\begin{array}{c}\% \\
\text { D }\end{array}$ & $\begin{array}{c}\% \\
\text { NDA }\end{array}$ & $\%$ A & $\begin{array}{c}\% \\
\text { SA }\end{array}$ \\
\hline $\begin{array}{l}\text { The ticket price is } \\
\text { reasonable. }\end{array}$ & 0 & 7 & 22.5 & 49.5 & 21 \\
\hline $\begin{array}{l}\text { The schedule and route } \\
\text { information provided at the } \\
\text { station is sufficient and easy } \\
\text { to get. }\end{array}$ & 3 & 7 & 20 & 51.5 & 18 \\
\hline $\begin{array}{l}\text { I feel safe while waiting at } \\
\text { the station. }\end{array}$ & 1.5 & 5 & 17.5 & 54.5 & 21.5 \\
\hline $\begin{array}{l}\text { Easiness and convenience on } \\
\text { booking or buying ticket. }\end{array}$ & 1.5 & 7 & 19 & 50.5 & 22 \\
\hline $\begin{array}{l}\text { The environment at the } \\
\text { station is clean. }\end{array}$ & 6 & 9 & 24.5 & 42 & 18.5 \\
\hline $\begin{array}{l}\text { I am satisfied with the route } \\
\text { waiting time. }\end{array}$ & 10 & 15 & 23.5 & 34 & 17.5 \\
\hline $\begin{array}{l}\text { I am satisfied with the route } \\
\text { travel time. }\end{array}$ & 5.5 & 11 & 20 & 45.5 & 18 \\
\hline
\end{tabular}

Note that $\mathrm{SD}=$ Strongly Disagree; $\mathrm{D}=$ Disagree NDA $=$ Neither Disagree nor Agree; A = Agree; SA = Strongly Agree

Table 3 shows that $70.5 \%$ of the respondents agree that the ticket price of the LRT is reasonable; $69.5 \%$ agree that the information pertaining to schedules and routes is sufficient; $76 \%$ feel safe while waiting at stations; $72.5 \%$ feel easy and convenient to book or buy ticket; $60.5 \%$ agree that the station is clean; $51.5 \%$ are satisfied with the route waiting time; $63.5 \%$ are satisfied with the route travel time. It can be surmised that the majority of LRT users are satisfied with its current environment and system.

Next, the exploratory factor analysis with principal component analysis and direct oblimin rotation was used to examine the data set. The results of Bartlett's test of sphericity statistic is $0.000(p<0.05)$, which supports the factorability of the correlation matrix. Moreover, the Kaiser-Meyer-Olkin measure of sampling adequacy (KMO) test value is 0.891 , which exceeds the recommended minimum value of 0.6 for a good factor analysis [31]. The results of the exploratory factor analysis using the principal component analysis and correlation between the items are shown in Table 4.

Table 4. Principal component analysis and correlation between items

\begin{tabular}{|c|c|c|c|c|c|c|c|}
\hline \multirow{2}{*}{ Item } & \multirow{2}{*}{ Factor loading } & \multicolumn{6}{|c|}{ Correlations } \\
\hline & & 1 & 2 & 3 & 4 & 5 & 6 \\
\hline The ticket price is reasonable. & 0.706 & & & & & & \\
\hline $\begin{array}{l}\text { The schedule and route information } \\
\text { provided at the station is sufficient and easy } \\
\text { to get. }\end{array}$ & 0.772 & $.531^{* *}$ & & & & & \\
\hline I feel safe while waiting at the station. & 0.779 & $.468^{* *}$ & $.545^{* *}$ & & & & \\
\hline $\begin{array}{l}\text { Easiness and convenience on booking or } \\
\text { buying ticket. }\end{array}$ & 0.808 & $.573^{* *}$ & $.667^{* *}$ & $.626^{* *}$ & & & \\
\hline The environment at the station is clean. & 0.887 & $.510^{* *}$ & $.596^{* *}$ & $.602^{* *}$ & $.634^{* *}$ & & \\
\hline I am satisfied with the route waiting time. & 0.881 & $.523^{* *}$ & $.553^{* *}$ & $.566^{* *}$ & $.550^{* *}$ & $.830^{* *}$ & \\
\hline I am satisfied with the route travel time. & 0.863 & $.507^{* *}$ & $.549^{* *}$ & $.654^{* *}$ & $.586^{* *}$ & $.829^{* *}$ & $.843^{* *}$ \\
\hline
\end{tabular}

Note: **Correlation is significant at the 0.01 level (2-tailed). 
Table 4 shows that all the items with factor loading which are greater than 0.40 . Thus, there are no items that will be deleted. Then, the correlation matrix that is obtained from the Table 4 shows statistically significant and moderate to high correlations among the observed indicators used in the analysis, especially the route waiting time and travel time that has the strongest positive correlation which is 0.843 compared to others. Whiler the relationship between routes waiting time and cleanness of station is also strong positively correlated which is 0.830 . Meanwhile, the relationship between other items such as cost, route information, safety, and ticket selling are weakly positively correlated.

All of the items used in this study confirmed that it can be one of the determinants to encourage LRT users to choose their own mode choice of transportation. The results are supported by Roberts [14], both of whom posited that the determinants influencing transportation modes for the citizen include frequency, travel time, cost, service, comfort, and cleanliness.

\section{Conclusions}

This study investigated user perception(s) on the usage of LRT and the correlation between multiple items. The results indicated that the highest usage of LRT is to school/college/university. Additionally, most of the LRT users agree with the items on LRT, such as reasonable ticket price, the sufficiency of information provided, feeling of safety, the cleanliness of the stations, the user friendliness of the payment system, the available routes, and waiting/travel times are all acceptable. There are $76 \%$ of the LRT users feeling safe while waiting at the station. However, the highest dissatisfied rate is waiting time. There are about $25 \%$ of the users who stated that there are not satisfaction with the route waiting time. The stakeholders should reschedule the railway timetable especially during peak hours because the majority of the respondents use LRT for commuting to school/college/university and work. User perception on using the LRT allowed us to pinpoint the issues and challenges that could be used to evaluate the quality of the public transport and suggest approaches that would result in its improvement. The measurement of the determinant attribute of residents' choices when traveling would result in information that unveils crucial information on the needs of customers in the context of improving the overall performance of public transportation systems.

\section{Acknowledgements}

The authors would like to extend their gratitude to the Research Management and Innovation Centre (RMIC), Sultan Idris Education University (UPSI) for the University Research Grants (code: 2018-0082-106-01) that helped fund the research.

\section{REFERENCES}

[1] Eleventh Malaysia Plan. Eleventh Malaysia Plan 2016-2020: Anchoring Growth on People, Malaysia, 2015.

[2] The Sun Daily (September 25, 2018), Signalling Fault Caused Peak Hour Delay of Kelana Jaya LRT line, Online available from https://www.thesundaily.my/archive/signall ing-fault-caused-peak-hour-delay-kelana-jaya-lrt-line-FUA RCH580492

[3] S. Bachok, M. M. Osman, Z. Ponrahono. Passenger's Aspiration towards Sustainable Public Transportation System: Kerian District, Perak, Malaysia, Procedia Social and Behavioral Sciences, Vol. 153, 553-565, 2014.

[4] O. Phoebe. Factors Influencing Customer Satisfaction in Public Transport Sector: A Case of Matatus in Central Business District Nairobi-Kenya, Thesis, University of Nairobi, Kenya, 2017.

[5] M. Hynes. At a Crossroads: Investigating Automobility and Its Implications for Local Urban Transport Policy Design, Urban Science, Vol. 1, No. 14, 1-16, 2017.

[6] R. Kamaruddin, O. Ismah, C. P. Che Anizaliana. Customer Expectations and its Relationship Towards Public Transport in Klang Valley, Journal of Asian Behavioural Studies, Vol. 2, No. 5, 29-38, 2017.

[7] S. Jain, M. Khare. Urban Air Quality Modelling: A Neuro-Fuzzy Approach, VDM Verlag Müller, Germany, 2010.

[8] M. L. Parry, O. F. Canziani, J. P. Palutikof, P. J. van der Linden, C. E. Hanson. Climate Change 2007: Impacts, Adapation and Vulnerability, Cambridge Univ. Press, United Kingdom, 2007.

[9] IEA. Energy Technology Perspectives 2016: Towards Sustainable Urban Energy Systems, International Energy Agency, France, 2016.

[10] G. Santos, H. Behrendt, L. Maconi, T. Shirvani, A. Teytelboym. Part I: Externalities and economic policies in road transport, Research in Transportation Economics, Vol. 28, No. 1, 2-45, 2010.

[11] U. A. Khalid, S. Bachok, M. M. Osman, M. Ibrahim. User Perceptions of Rail Public Transport Services in Kuala Lumpur, Procedia Social and Behavioral Sciences, Vol. 153, No. 16, 566-573, 2014.

[12] S. Fujii, R. Kitamura. What does a one-month free bus ticket do to habitual drivers? An experimental analysis of habit and attitude change, Transportation, Vol. 30, 81-95, 2003.

[13] M. Fellesson, M. Friman. Perceived satisfaction with public transport services in nine European cities, The Journal of Transportation Research Forum, Vol. 47, 93-103, 2008.

[14] K. Roberts. Key Factors and Trends in Transportation Mode and Carrier Selection, The Journal of Undergraduate Research at the University of Tennessee, Vol. 4, No. 1, 41-52, 2012. 
[15] G. Botzoris, A. Galanis, V. Profillidis, N. Eliou. Commuters Perspective on Urban Public Transport System Service Quality, WSEAS Transactions on Environment and Development, Vol. 11, 182-192, 2015.

[16] C. S. Leem, Y. Yoon. A maturity model and an evaluation system of software customer satisfaction: The case of software companies in Korea, Industrial Management \& Data Systems, Vol. 104, No. 4, 347-354, 2004.

[17] J. R. Aworemi, A. O. Salami, J. O. Adewoye, M. O. Ilori. Impact of socioeconomic characteristics on formal and informal public transport demands in Kwara state, Nigeria, African Journal of Business Management, Vol. 2, No. 4, 72-76, 2008.

[18] J. Pucher, N. Korattyswaropam, N. Mittal, N. Ittyerah. Urban Transport Crisis in India, Transport Policy, Vol. 12, No. 3, 185-198, 2005.

[19] L. Zheng, J. Wu. Summary of the Application Effect of Bus Rapid Transit at Beijing South-Centre Corridor of China, Journal of Transportation Systems Engineering and Information Technology, Vol.7, No.4, 137-142, 2007.

[20] H. I. M. Irtema, A. Ismail, S. I. Albrka, M. A. Ladin, H. A. Yahia. Evaluating the performance of traffic flow in four intersections and two roundabouts in Petaling Jaya and Kuala Lumpur using Sidra 4.0 software, Jurnal Teknologi, Vol. 72, No. 4, 1-5, 2015.

[21] R. Ismail, M. H. Hafezi, R. M. Nor, K. Ambak. Passengers Preference and Satisfaction of Public Transport in Malaysia, Australian Journal of Basic and Applied Sciences, Vol. 6, No. 8, 410-416, 2012

[22] M. Cantwell, B. Caulfield, M. O’Mahony. Examining the Factors that Impact Public Transport Commuting Satisfaction, Journal of Public Transportation, Vol. 12, No. 2, 1-21, 2009.

[23] T. Mmutle, L. Shonhe. Customers' perception of Service Quality and its impact on reputation in the Hospitality Industry, African Journal of Hospitality, Tourism and Leisure, Vol. 6, No. 3, 1-25, 2017.

[24] G. Sweis, R. Imam, G. Kassab, R. Sweis. Customer Satisfaction in Apartment Buildings: The Case of Jordan, Life Science Journal, Vol. 10, No. 12s, 237-245, 2013.

[25] S. Sumaedi, I. G. M. Y. Bakti, T. Rakhmawati, N. J. Astrini, T. Widianti, M. Yarmen. Factors influencing public transport passengers' satisfaction: a new model, Management of Environmental Quality: An International Journal, Vol. 27, No. 5, 585-597, 2016.

[26] A. Mouwen. Drivers of customer satisfaction with public transport services, Transportation Research Part A: Policy and Practice, Vol. 78, 1-20, 2015.

[27] J. S. Sharfuddin. Factor Analysis for the Study of Determinants of Public Transit Ridership, Journal of Public Transportation, Vol. 3, No. 3, 1-17, 2000.

[28] J. F. Hair Jr, W. C. Black, B. J. Babin, R. E. Anderson, R. L. Tatham. Multivariate data analysis (7th Ed.), Prentice-Hall, Upper Saddle River, NJ, 2010.

[29] A. G. Bluman. Elementary Statistics: A Step By Step Approach 10th Edition, McGraw-Hill Education, New York, 2017.
[30] M. Tavakol, R. Dennick. Making Sense of Cronbach's Alpha, International Journal of Medical Education, Vol. 2, 53-55, 2011.

[31] H. F. Kaiser. An index of factorial simplicity, Psychometrika, Vol. 39, 31-36, 1974. 